\title{
DIGITAL PUBLIC RELATIONS DEVELOPMENT FOR AGRICULTURAL TOURISM: CASE OF CHALOEM PHRAKIAT DISTRICT OF NAN PROVINCE
}

\section{Panupong Chanplin}

${ }^{1}$ Suan Sunandha Rajabhat University. Email: panupong.ch@ssru.ac.th

\begin{abstract}
The tourism sector has considerably increased in Nan province in last few years, and has made major contribution to the Nan province due it natural beauty and beautiful landscape. Agricultural tourism has emerged as new tourism attraction in this region. Thai government has initiated many agricultural tourism projects for increasing revenue of Thai people in rural and agricultural areas and give tourists insight and experience of rural life. This paper is designed to examine the agricultural tourism development in Chaloem Phra kiat District. This paper tests the relationship between digital public relation, sense of community and agricultural tourism development in case of Chaloem Phrakiat District. The data was collected from 351 respondents which was analyzed on structural equation modeling on SPSS to check hypothetical relationship among proposed research frame. The findings advocated that personal relationship, community relationship, professional relationship and agricultural tourism development are significantly correlated. Sense of community also intervenes the connection between these variables. The paper advances literature on Digital public relations and agricultural tourism in Thailand. This paper will benefit public relation experts and government of community building in Chaloem Phra kiat District.
\end{abstract}

\section{Keywords:}

Digital public relations development, Personal relationship, Community relationship, Professional relationship, Sense of community, Agricultural tourism, Nan Province, Thailand.

Article Received: 18 October 2020, Revised: 3 November 2020, Accepted: 24 December 2020

\section{Introduction}

Agriculture has an ancient history as human beings and agriculture is the major economic source for almost all countries around the globe (Wu, 2018). Agriculture has been regarded as the profession of remote areas and the people relating this field were kind of less educated and depicted to their old formal way of farming. The simplest way of life was a remarkable aspect and a great difference in the life routine of the rural and urban communities (Anderson, 2018). Now the modern age has revolutionized every field and especially in the field of agriculture. Agri-tourism is the modern form of visiting agricultural farms with a lot of variations and innovations to attract more and more tourists to attract to visit the major fields and promote tourism.

The below table entails the importance of DPR in managing the online reputation of agriculture tourism;

\begin{tabular}{|c|c|}
\hline Blog posts & Improve the business reputation mainly by ORM. \\
\hline Review sites & Remove/reduce negative links or relationships. \\
\hline Press releases & $\begin{array}{l}\text { Business reviews and past consumers competitors websites and } \\
\text { forums. }\end{array}$ \\
\hline Social media & $\begin{array}{l}\text { Developing a personal or service image, special SEO strategies } \\
\text { mainly for ORM strategies. }\end{array}$ \\
\hline Forums & $\begin{array}{l}\text { Remove/reduce unfavorable comments finding out what } \\
\text { individuals are saying. }\end{array}$ \\
\hline
\end{tabular}


Many scholars and analysts have emphasized the significance of establishing and controlling linkages among public and governments such as Zhang (2019) they mainly focused on the advantages of effective and strong association that allow local governments to attain its desire objectives mainly such as loyalty to the local government; though, it is significant that effective linkages can not only create public support for government practices but can also generate some type of capital, which according to Mees (2017) maintains democratic conditions and environment. Nevertheless, several researchers have emphasized the relationships between tourism capital, public relations, and the term democracy such as Huang, Wu, and Huang (2017) it remains unclear and significant how digital public relations (DPR) can improve the performance of agriculture tourism. Hence, to address this limitation and gap the present study aims to provisionally investigate how the independent variables of DPR are connected to the sense of community (SoC), which further affects the public's relations and engagement in agriculture tourism improvement and development.

Furthermore, the below graph has shown the major source countries of agricultural imports for Nan-province.

\section{Thailand major agricultural import sources}

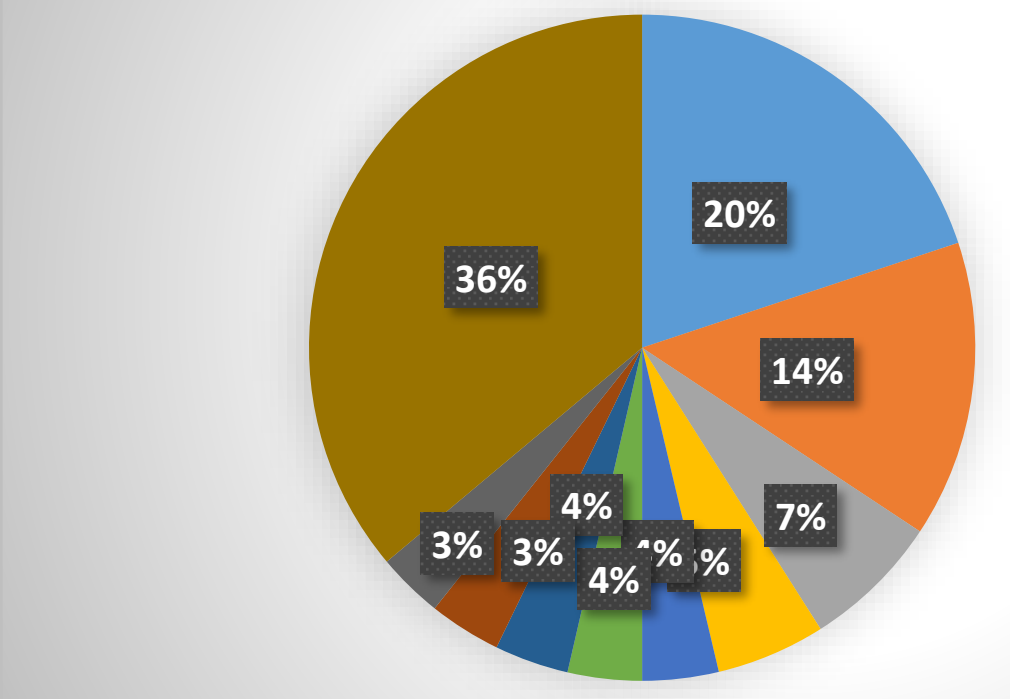

China
Japan

U.S

Malaysia

Taiwan

South Korea

Singapore

U.A.E
In the line of the above statement of justification, the major target of the following paper is to analyze the overall impact of DPR on the agriculture tourism development (ATD) in Chaloem Phrakiat District of Nan Province; another aim of the study is to evaluate the exclusive impact of personal relationship (PR) on the ATD of the region. The second objective is to identify the interrelation between community relationship (CR) and ATD of the Phrakiat district, and the third purpose is to investigate the significant impact of professional relationship (PR) on the ATD of the region. And finally, the last aim of the paper is to evaluate the mediating role of SoC in improving the current association between PR, CR, PR, and ATD of the district.

Moreover, the findings of the present research indicate practical as well as the theoretical significance of the mediating influence and part of the SoC in managing associations for both practice and theory. Besides, the verdicts of the given paper have a wider scope for agriculture experts in understanding the significance of DPR in developing and controlling effective ATD of the district. Furthermore, the rest of the study is framed as; review of the literature, methodology of the study, analysis, and interpretation of results, 
and conclusion and discussion along with implications of findings.

\section{Literature review}

\section{Theory of DPR}

Ivy Lee and his fellow Louis Bernays, developed the initial demonstration of public relations theory in the early 1990s as follows; a management practice which organizes and manage public attitudes, manifests the procedures, policies, and interest of a sector, mainly followed by implementing a program of action to get public acceptance and interest(Wright \& Hinson, 2017). According to Bernays, the PR counsel is the main agent performing with both modern media of transmission and communication and group establishment of society to give ideas to the public's consciousness to achieve desire goals in terms of any particular sector development(Soylu, 2018). Furthermore, this theory also states that DPRs are the foundation of sector development mainly through the use of the internet to communicate with currents as well as potential customers in the realm by encouraging personal and community relationships.

The relationship between personal relationship and agriculture tourism development

According to Kamolov (2017), PR reveals the several methods and techniques a sector and particular industry uses to disseminate messages mainly about its services, products, and the entire image of the sector to its customers and visitors and other interested individuals of the community. The primary point of these types of relationships according to Men, Tsai, Chen, and Ji (2018) is to make the individuals think favorably and significantly about the industry and its services and offerings. Commonly used techniques and instruments to build effective PR include news releases, personal service programs, speaking engagement, and other means (Nurjanah \& Nurnisya, 2016). Even though advertising is closely and best related to PRs as it is too concerned with promoting as well as acquiring personal acceptance for the sector's offerings and products (Dodd \& Collins, 2017). The objective of personal acceptance is to generate effective business development, while the purpose of PRs is generating significant will. The above theory of DPR supports the association between PR and ATD because according to this theory PR aims to develop efficient service value while using digital tools to promote PRs. Thus, the given study proposes the following hypothesis;

H1: There is a direct and significant relationship between personal relationships and agriculture tourism establishment.

The association between community relationship and agriculture tourism growth

A study by Moghavvemi, Woosnam, Paramanathan, Musa, and Hamzah (2017) demonstrate that CR simply describes a sector's interactions with the community in which it locates, and this directly impacts the development of the sector. The use of this relationship by the tourism sector, the media, and scholars of tourism, though, almost always signifies something more than simple associations and connections and also include voluntary actions that are or can be interpreted as done just for the significance of the community (Rasoolimanesh, Jaafar, Ahmad, \& Barghi, 2017). According to Lai and Hitchcock (2017), the main objective of this type of relationship is to develop, maintain and protect the tourism sector's reputation, and also improve its prestige and develop a favorable image of agriculture tourism in the community of the region. Studies like Eslami, Khalifah, Mardani, Streimikiene, and Han (2019) have indicated that visitors and customers often base their purchase decisions on a firm's and sector's reputation, therefore, CR can have a definite impact on the development as well as revenue of the tourism sector. Hence, based on the above discussion the researchers hypothesized that;

H2: Community relationship directly and significantly relates to agriculture tourism development. 
The correspondence between professional relationship and agriculture tourism development

Agricultural-tourism is a subset of rural tourism that comprises resorts, on profit agriculture tours, off-site farmers' markets, and addition with the leisure and hospitality businesses that attract visitors to the countryside(Olsen, Vogt, \& Andereck, 2018). Agricultural-tourism describes any activity, business, or enterprise that links agriculture with services, products, and experiences in tourism development. A professional relationship is the set of code or system to attract the visitors and provide them with the facilities and needs to provide the tourists with the excellence the tourism in the rural areas can be a successful field when all the aspects of agriculture providers are at the platform to manage all the responsibilities(Suess, Baloglu, \& Busser, 2018). There is a kind of positive relationship in promoting Agricultural-tourism when there is a perfect combination in agriculture tourism management. Thus, the study hypothesized that;

H3: Professional relationships directly and positively relates to agriculture tourism development.

The mediating role of sense of community in the correspondence between personal relationship and agriculture tourism development

Petric and Pivcevic (2016) defined PR as a significant and active attempt to restore and control SoC, and according to Pickett, Goldsmith, Damon, and Walker (2016), the term SoC is generally invoked to demonstrate the connection between the public and social settings. Hahm, Breiter, Severt, Wang, and Fjelstul (2016), in a study, determines that $\mathrm{SoC}$ is a broad concept in community social work, as well as in many other research disciplines which mainly focuses on the experience of community and its role in the overall development of the business(Zhu, Liu, Wei, Li, \& Wang, 2017). Moreover, many researchers have investigated the impact and role of SoCin business development such as (M. J.
Kim, Lee, \& Jung, 2020). These researchers have identified the association between SoC and personal participation (PP) and have revealed PP as a significant factor in tourism development. Consequently, the present research predicts the below hypothesis;

H4: Sense of community positively mediates the relationship between personal relationships and ATD.

The mediating influence of sense of community in the interrelation between community relationship and agriculture tourism growth

To promote agriculture tourism growth, there must be a complete collaboration and an organized system only possible with the community relationship(Hampton, Jeyacheya, \& Long, 2018). The rural or urban communities are quite different in lifestyles and habitual of the different setup of facilities. The sense of community, the need for the system, and areas according to the community has different aspects. The need of the rural community is to take such steps to develop modern facilities to promote the Agricultural-tourism and the urban communities feel a great difference in spending their leisure time with a close observation of nature and natural beauty(Leonard \& Lebogang, 2018). Thus, this link of communities to provide services to visit rural areas, and the provision of all facilities to the tourists leads to a continuous system of promoting Agricultural-tourism. Consequently, the given study proposes the below hypothesis;

H5: Sense of community significantly mediates the nexus between community relationships and ATD.

The mediating impact of sense of community on the relationship between a professional relationship and agriculture tourism growth

A professional relationship is necessary to build a connection and attraction of the tourists with a perfect system of services and natural beauty to satisfy their sense of tourism, spending leisure time in observing nature with all the facilities to visit those places(Xue, Kerstetter, \& Hunt, 2017). Agriculture tourism is the field that intends to 
provide facilities of resorts, restaurants, fresh vegetables, and fruits also the dealing of fresh green items all over the country .sense of the community has a very meditating impact as to promote the growth of agriculture tourism. SoC promotes providing all the requirements and to fulfill the demands of the tourists so that they may satisfy to visit agriculture tourism (Naidoo \& Sharpley, 2016). The study very clearly expresses the impact of the sense of community in promoting tourism growth in the field of agriculture and the professional relationship. So, based on the above discussion the research suggests that;

H6: Sense of community favorably mediates the interdependence between a professional relationship and ADT.

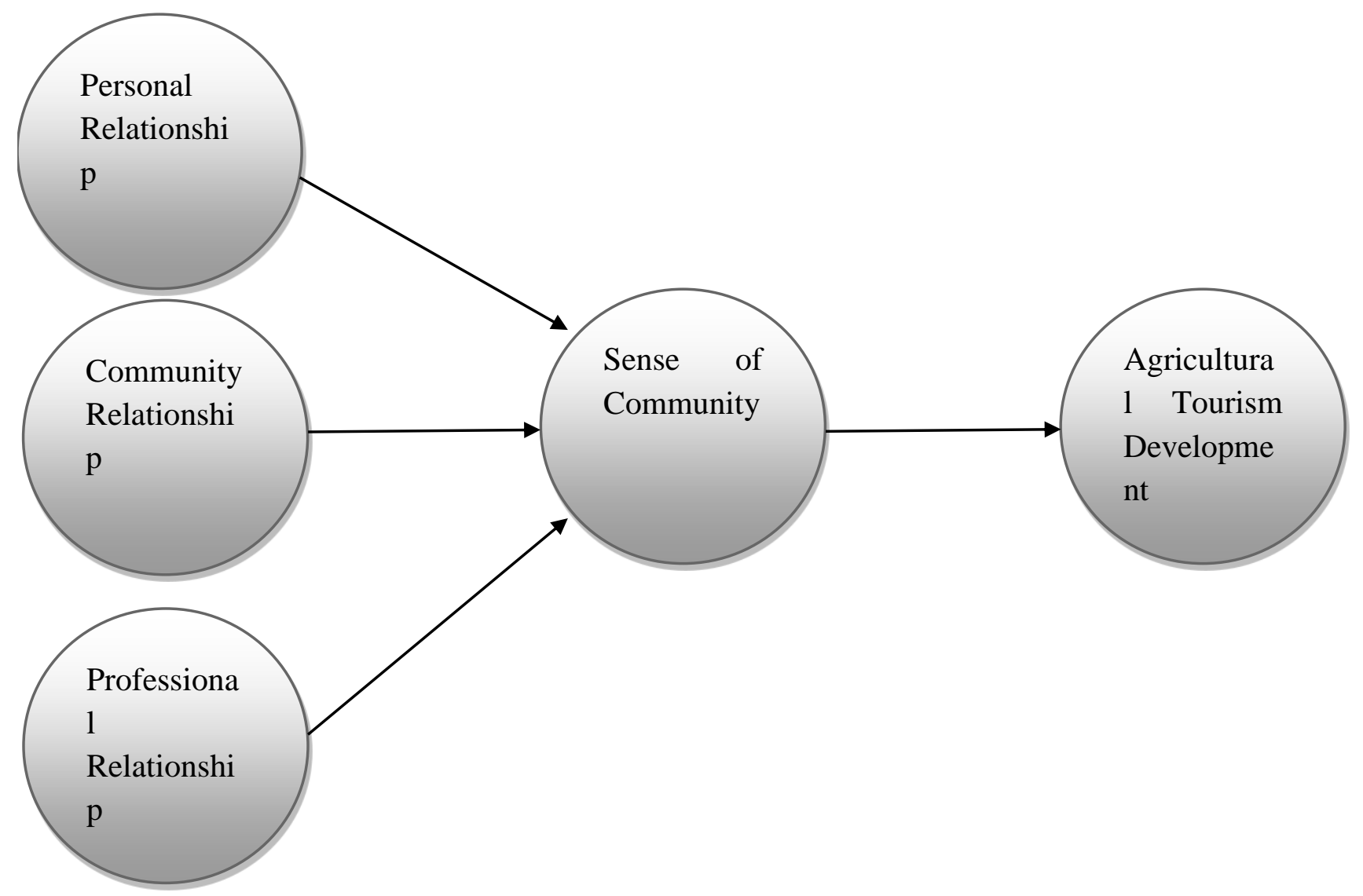

Figure 2: Model s

\section{Methodology}

\section{Method and sample}

A quantitate approach was opted to quantify data from a purposive sample of 351 respondents from Thai Royal Projects scheme in Chaloem Phrakiat District. This approach was opted in view of current paper requirement to show a cause and effect relationship between public relations and agricultural development. A survey was plotted in agro-tourism destinations of from Chaloem Phrakiat District, to get data from tourists. Those tourists were targeted who have visited these agricultural areas and have interacted digital public relation. A questionnaire was developed which was self-reporting and designed carefully keep in mind the ease and awareness of respondents. The confirmed questionnaire was directed towards 436 respondents in Nan province district, and distributed via a URL attached email. The survey was completed between June and July. Total 1000 emails were spread only 550 were received among which 199 were not usable so only 351 were opted for analysis. 


\section{Instrument}

The instrument of this paper is a selfadministrative questionnaire, that consists of several items derived from previous scales. The questionnaire has questions requiring respondent's personal information like age, gender, nationality. It also encompasses questions regarding digital public relation, sense of community and agricultural tourism development.

Here digital public relation was measured into three dimensions' Personal relationship, Community relationship, Professional relationship. For estimation of these dimensions nine items were drawn from Ledingham (2001) public relation scale. Each dimension was measured by three items to see the use of digital public relation in agricultural tourism to communicate with people. One of the three items for measuring personal relationship is "I feel that I can trust my city officials to do what they say they will do," other three items measured community relationship by stating an item "My city officials are open about their plans for the future," for validation of professional relationship three items are adapted "I think my city officials are honest in dealings with residents". All these items are rated by respondents on a five-point Likert type scale. Which labelled responses from 1=strongly disagree, $2=$ disagree, $3=$ neutral, $4=$ agree and
$5=$ strongly agree. Peterson, Speer, and McMillan (2008) sense of community scale was reviewed to develop items for evaluating the sense of community for which five items were elected. These items include "I feel connected with others in my neighborhood" respondents put forward their sense of community on five-point scale.

\section{Results and Analysis}

To take into account the role digital public relations in development of agricultural tourism in Chaloem Phrakiat District of Nan province based on a purposive sampling recruiting 351 respondents, On the inspection of data, demographics such as gender, age and education was also identified. In respondents, males were 193 (55.0\%), and among them 158 were female (45.0\%) means most of the locals are males. In addition, 115 respondents (32.85) age is less than 25 years old, 138 are up to 25 to 35 Years (39.3\%) whereas $83(23.6 \%)$ are 35 to 45 Years old and only 15 were aged above 45 (4.3\%) so most of the respondents are young in age. The respondents experience in digital public relation and agriculture was also recoded $(13.4 \%$ - 47 informants) Less than 2 Years' experience, (43.6\%-153 informants) 2 to 5 Years of experience, (33.6\% - 118 informants) 5 to 8 Years and (9.4\% - 33 informants) have more than 8 Years

of experience.

Table 2: Descriptive Statistics

\begin{tabular}{llllllll}
\hline & $\mathrm{N}$ & \multicolumn{3}{c}{ Minimum } & Maximum & Mean & \multicolumn{3}{c}{ Std. Deviation Skewness } \\
\cline { 2 - 7 } & Statistic & Statistic & Statistic & Statistic & Statistic & Statistic & Std. Error \\
\hline PerRelation & 351 & 1.00 & 5.00 & 3.2569 & 1.04461 & -.151 & .130 \\
ComRelation & 351 & 1.00 & 5.00 & 3.3887 & 1.03368 & -.346 & .130 \\
ProRelation & 351 & 1.00 & 5.00 & 3.5539 & 1.19707 & -.573 & .130 \\
SensComm & 351 & 1.00 & 5.28 & 3.4672 & 1.12600 & -.543 & .130 \\
AgrTourDev & 351 & 1.00 & 5.00 & 3.5831 & 1.14058 & -.580 & .130 \\
Valid & $\mathrm{N} 351$ & & & & & & \\
(listwise) & & & & & & & \\
\hline
\end{tabular}

In table the precise of sample is quantified in form of descriptive statistics. Total observations were symbolized as $\mathrm{N}$, in this model 351 total observation been there. Outliers are not detected 4 constructs as minimum and maximum values are 1 and 5. But Sense of community encountered an 
outlier as it maximum value is 5.28. The means statistics presented the tendency of responses, mean value of personal relationship, community relationship, professional relationship, sense of community and agricultural tourism development were $3.2569,3.3887,3.5539,3.4672$ and 3.5831 which approaching towards 3.5, endorsing appropriate agreeability. Skewness statistics values were within -1 and +1 which supported the normal distribution of data so descriptive statistics also confirmed normal distribution.

Table 3: KMO and Bartlett's Test

\begin{tabular}{lll}
\hline Kaiser-Meyer-Olkin Measure of Sampling Adequacy. & .903 \\
Bartlett's Test of Sphericity & Approx. Chi-Square & 6906.087 \\
& df & 153 \\
& Sig. & .000 \\
\hline
\end{tabular}

Kaiser-Meyer-Olkin Measure and Bartlett's Test of Sphericity are tools for assessing appropriateness of sampling size that either it is in right fit for research or not. The results anticipated Sampling Adequacy=.903 which is lying between 0.8 and 1 which favored the adequacy of size of sample. In Bartlett's Test of Sphericity. The Estimated Chi-square $=6906.087$ and endorsing
153 degree of freedom is also a confirming sample suitability

Table 3 showed the Factor loading for items calculated by Confirmatory factor analysis. Rotated Component Matrix essentially postulates data accuracy and validity. All the item's factor loading is greater than 0.7 and there is no cross loading error reported which confirms data is valid and accurate.

Table 4: Rotated Component Matrix ${ }^{\mathrm{a}}$

\begin{tabular}{|c|c|c|c|c|c|}
\hline & \multicolumn{5}{|c|}{ Component } \\
\hline & 1 & 2 & 3 & 4 & 5 \\
\hline PR1 & & & & .810 & \\
\hline PR2 & & & & .879 & \\
\hline PR3 & & & & .831 & \\
\hline CR1 & & & & & .820 \\
\hline CR2 & & & & & .813 \\
\hline CR3 & & & & & .819 \\
\hline PF1 & & & .865 & & \\
\hline PF2 & & & .874 & & \\
\hline PF3 & & & .844 & & \\
\hline SC1 & .841 & & & & \\
\hline SC2 & .861 & & & & \\
\hline SC3 & .844 & & & & \\
\hline $\mathrm{SC} 4$ & .862 & & & & \\
\hline SC5 & .882 & & & & \\
\hline TD1 & & .784 & & & \\
\hline TD2 & & .818 & & & \\
\hline TD3 & & .854 & & & \\
\hline TD4 & & .854 & & & \\
\hline
\end{tabular}


Table 5: Convergent and Discriminant Validity

\begin{tabular}{lllllllll}
\hline & CR & AVE & MSV & SC & PR & CR & PF & TD \\
\hline SC & 0.962 & 0.836 & 0.393 & $\mathbf{0 . 9 1 4}$ & & & & \\
PR & 0.895 & 0.739 & 0.331 & 0.469 & $\mathbf{0 . 8 6 0}$ & & & \\
CR & 0.898 & 0.746 & 0.331 & 0.538 & 0.575 & $\mathbf{0 . 8 6 4}$ & & \\
PF & 0.923 & 0.822 & 0.393 & 0.627 & 0.465 & 0.574 & $\mathbf{0 . 8 4 7}$ & \\
TD & 0.922 & 0.747 & 0.331 & 0.512 & 0.506 & 0.464 & 0.533 & $\mathbf{0 . 8 6 6}$
\end{tabular}

Table 4 slot in the outcomes for Convergent and Discriminant Validity. Values designated that sense of community preserve highest composite reliability 0.962 demonstrating internal consistency. Personal relation entitled lowest composite reliability as 0.895 . Composite reliability values are more than 0.6 that is enough for variable satisfactory reliability. Average variance extracted indicated that sense of community has highest variance due to $\mathrm{AVE}=$ 0.836 and personal relation holds lowest variance as AVE is 0.739 which also meeting the criteria $>0.7$ so it is confirmed that data has convergence which is valid. The above table also consisted of discriminant validity, the diagonal array values which are different from previous ones and higher than MVE shows discernment validity.

Table 6: Model Fit Indices

\begin{tabular}{llllll}
\hline CFA Indicators & CMIN/DF & GFI & IFI & CFI & RMSEA \\
\hline Threshold Value & $\leq 3$ & $\geq 0.80$ & $\geq 0.90$ & $\geq 0.90$ & $\leq 0.08$ \\
Observed Value & 2.534 & 0.870 & 0.954 & 0.954 & 0.075 \\
\hline
\end{tabular}

Table 5 of model fitness is fitness test to check eiher model is appliacble for research analysis or not. The value for CMIN/DF $=2.534$ is $\leq 3$, GFI (goodness of fit index ) $=.0 .870$ is $\geq 0.80$, CFI (comparative fit index) $=0.954$ and IFI (incremental fit index) $=.0 .954$ is $\geq .90$, and $\mathrm{RMSEA}=0.075$ is $\leq .80$. The current values are evedencing that model is fit to the research persepective (Hameed, Basheer, Iqbal, Anwar, \&
Ahmad, 2018; Hassan, Hameed, Basheer, \& Ali, 2020; Shaffee, Ahmad, Idris, Ismail, \& Ghani, 2019; Subramaniam \& Anandasayanan, 2018; Taiwo, Alagöz, \& Erdoğan, 2020; Tang, 2019; Tarus, Tenai, \& Komen, 2020; Thomas, Fullerton, \& Saenz, 2018; Tong \& Baslom, 2019; UlHameed, Mohammad, \& Shahar, 2018; Yen, Chang, Tien, Shen, \& Chang, 2019; Yusufzada et al.,

2020;

Zahran,

Figure 3: CFA

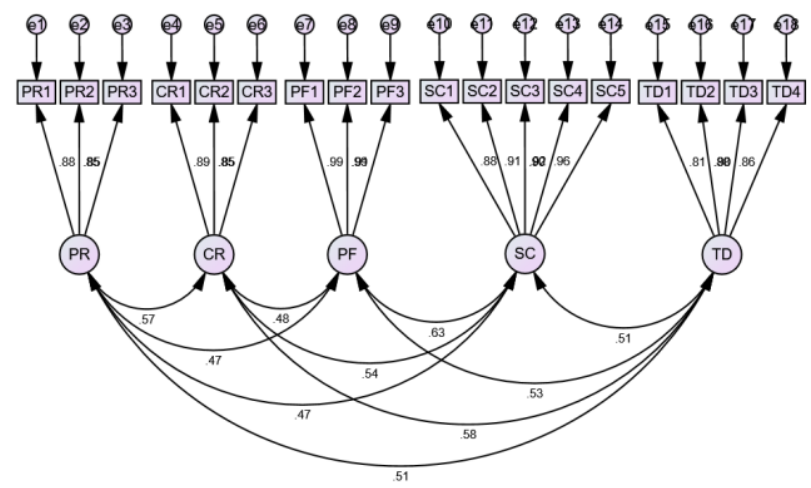


Table 7: Structural Equation Modeling

\begin{tabular}{lllll}
\hline Total Effect & ProRelation & ComRelation & PerRelation & SensComm \\
\hline SensComm & $.413^{* *}$ & $.182^{* *}$ & $.180^{* *}$ & .000 \\
AgrTourDev & $.279 * *$ & $.294^{* *}$ & $.176^{* *}$ & $.228^{* *}$ \\
Direct Effect & ProRelation & ComRelation & PerRelation & SensComm \\
SensComm & $.413^{* *}$ & $.182^{* *}$ & $.180^{* *}$ & .000 \\
AgrTourDev & $.184^{*}$ & $.252^{* *}$ & $.135^{* *}$ & $.228^{* *}$ \\
Indirect Effect & ProRelation & ComRelation & PerRelation & SensComm \\
SensComm & .000 & .000 & .000 & .000 \\
AgrTourDev & $.094 * *$ & $.042^{* *}$ & $.041^{* *}$ & .000 \\
\hline
\end{tabular}

The SEM results concerning hypothetical relationship of proposed relationship among public relations, sense of community and agricultural tourism development is summarized in table 6 . The results provided basis for deciding which hypothesis is acceptable and which is reject-able. The paper showed that one-unit increment, caused increase of $41.3 \%$ in sense of community, $18.4 \%$ in agricultural tourism development, which is a confirmation of significant direct effect which obviously made these hypotheses acceptable. The community and professional relation positively enrich agricultural tourism development by $25.2 \%$ and $13.5 \%$ respectively. Moreover, sense of community embraces significant indirect impression on agricultural tourism development through public relations and sense of community management as single unit change will lift agricultural tourism development by $9.4 \%, 4.2 \%$ and $4.1 \%$. So results indicated that all hypotheses are approved.

Figure 4: SEM

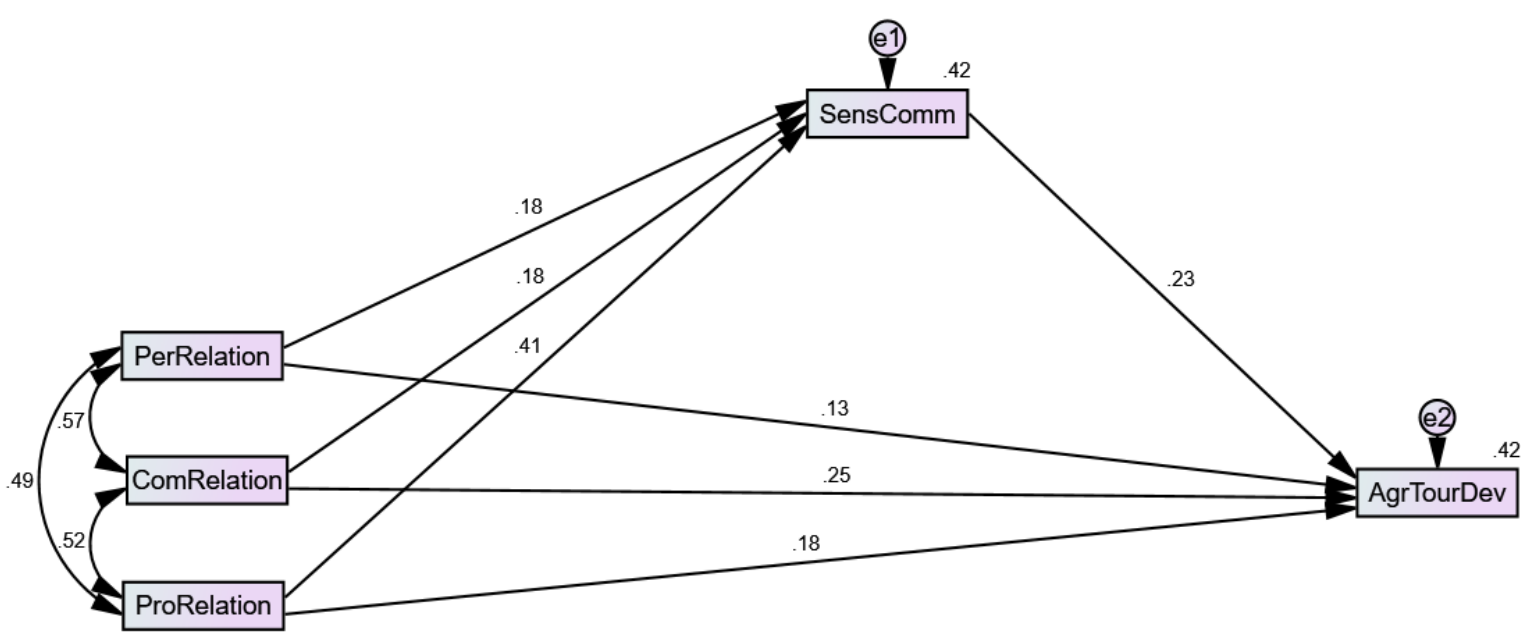

\section{Discussion and Conclusion}

The public relation has been studied extensively in past and it has gained great amount of attention from researchers and professional as well (Rahi \& Abd Ghani, 2016). However, the role of digital public relation in tourism development is not well explored especially there is lack of theoretical and practical work on digital public relation in context of agricultural tourism. To comprehend how digital public relation impact agricultural tourism development this study was administered in Nan province 'Chaloem Phrakiat District. For 
statistical proof of these relationship different hypotheses were generated in reference to previous theories and studies. The studies discovered that personal relationship significantly impact local's participation in development of agricultural tourism development. So the H1 that was proposing a significant relationship among personal relationship and agricultural tourism development. The professional relations are also very import for developing agriculture tourism. $\mathrm{H} 2$ projected a significant relationship between professional relation and agricultural tourism which was approved by statistical outcomes. As when a professional assistance is provided to local community its helps in developing and promoting agricultural tourism (M. Kim \& Cho, 2019). This study also hypothesized the relationship between community relations and agricultural tourism development in $\mathrm{H} 3$ which forecasted a significant relationship between community relations and agricultural tourism. It was detected that community relation encourage agricultural development (Sanders \& Canel, 2015) stated that when government interests are aligned with community interests it gives rise to development of agro-tourism. Moreover, the study also revealed that Sense of community positively mediates the relationship between personal relationships and agro-tourism development (H4). As attachment and belonging to community nurtures good personal relation that encourages to build agricultural tourism (M. J. Kim et al., 2020). Sense of community meditating relationship was hypothesized in (H5) as Sense of community significantly mediates the nexus between community relationships and ATD which was also proved and postulated that the sense of community evokes community relation by enhancing attachment that's play an important role in developing agricultural tourism. The paper found out that sense of community also mediated professional relations and development (H6) due to positive impact. Sense of community shapes professional relations that boost development as per (Omoto \& Packard, 2016).
This paper presents that digital public relation is becoming need of hour due to rapid digitalization like other sectors agriculture and tourism is not untouched from its consequences. These relations hold important place in building agriculturaltourism as shown by results, so it is important to maintain digital public relation to develop sense of community and agricultural tourism. This paper will be considered a major contributor in digital public relation in agriculture tourism literature as it is known to be first study which has linked digital public relation with agriculture tourism development in Thailand. It is also useful in terms of practical implementation due to important findings and insights. It guides organization to assimilate public relation to form trust and communication between public for development of community. Government can learn that how to develop sense of community which will provide benefit to society as a whole. Few limitations are also acknowledged which opens endeavors for future researches this paper is only conducted in a district of Nan province agricultural sector so it is not generalizable to other sectors. Moreover, an online survey was used to fetch data so there is still a chance of response bias so a self- directed survey can also be used.

\section{REFERENCES}

[1] Anderson, W. (2018). Linkages between tourism and agriculture for inclusive development in Tanzania. Journal of Hospitality and Tourism Insights.

[2] Dodd, M. D., \& Collins, S. J. (2017). Public relations message strategies and public diplomacy 2.0: An empirical analysis using Central-Eastern European and Western Embassy Twitter accounts. Public relations review, 43(2), 417-425.

[3] Eslami, S., Khalifah, Z., Mardani, A., Streimikiene, D., \& Han, H. (2019). Community attachment, tourism impacts, quality of life and residents' support for sustainable tourism development. Journal of 
Travel \& Tourism Marketing, 36(9), 10611079.

[4] Hahm, J. J., Breiter, D., Severt, K., Wang, Y., \& Fjelstul, J. (2016). The relationship between sense of community and satisfaction on future intentions to attend an association's annual meeting. Tourism Management, 52, 151-160.

[5] Hameed, W. U., Basheer, M. F., Iqbal, J., Anwar, A., \& Ahmad, H. K. (2018). Determinants of Firm's open innovation performance and the role of $\mathrm{R} \& \mathrm{D}$ department: an empirical evidence from Malaysian SME's. Journal of Global Entrepreneurship Research, 8(1), 29.

[6] Hampton, M. P., Jeyacheya, J., \& Long, P. H. (2018). Can tourism promote inclusive growth? Supply chains, ownership and employment in Ha Long Bay, Vietnam. The Journal of Development Studies, 54(2), 359376.

[7] Hassan, S. G., Hameed, W. U., Basheer, M. F., \& Ali, J. (2020). ZAKAT COMPLIANCE INTENTION AMONG SELF-EMPLOYED PEOPLE: EVIDENCE FROM PUNJAB, PAKISTAN. $A L-A D W A H, 34(2), 80-96$.

[8] Huang, Y.-H. C., Wu, F., \& Huang, Q. (2017). Does research on digital public relations indicate a paradigm shift? An analysis and critique of recent trends. Telematics and informatics, 34(7), 13641376.

[9] Kamolov, S. G. (2017). Digital public governance: trends and risks. Giornale di storia costituzionale, 33, 185.

[10] Kim, M., \& Cho, M. (2019). Examining the role of sense of community: Linking local government public relationships and community-building. Public Relations Review, 45(2), 297-306.

[11] Kim, M. J., Lee, C.-K., \& Jung, T. (2020). Exploring consumer behavior in virtual reality tourism using an extended stimulusorganism-response model. Journal of Travel Research, 59(1), 69-89.
[12] Lai, I. K. W., \& Hitchcock, M. (2017). Local reactions to mass tourism and community tourism development in Macau. Journal of Sustainable Tourism, 25(4), 451-470.

[13] Ledingham, J. A. (2001). Governmentcommunity relationships: Extending the relational theory of public relations. Public Relations Review, 27(3), 285-295.

[14] Leonard, L., \& Lebogang, T. (2018). Exploring the impacts of mining on tourism growth and local sustainability: The case of Mapungubwe Heritage Site, Limpopo, South Africa. Sustainable development, 26(3), 206216.

[15] Mees, H. (2017). Local governments in the driving seat? A comparative analysis of public and private responsibilities for adaptation to climate change in European and North-American cities. Journal of Environmental Policy \& Planning, 19(4), 374-390.

[16] Men, L. R., Tsai, W.-H. S., Chen, Z. F., \& Ji, Y. G. (2018). Social presence and digital dialogic communication: Engagement lessons from top social CEOs. Journal of Public Relations Research, 30(3), 83-99.

[17] Moghavvemi, S., Woosnam, K. M., Paramanathan, T., Musa, G., \& Hamzah, A. (2017). The effect of residents' personality, emotional solidarity, and community commitment on support for tourism development. Tourism Management, 63, 242254.

[18] Naidoo, P., \& Sharpley, R. (2016). Local perceptions of the relative contributions of enclave tourism and agritourism to community well-being: The case of Mauritius. Journal of Destination Marketing \& Management, 5(1), 16-25.

[19] Nurjanah, A., \& Nurnisya, F. Y. (2016). Pemanfaatan Digital Public Relations (PR) dalam Sosialisasi Tagline "Jogja Istimewa" Humas Pemerintah Kota Yogyakarta. ARISTO, 4(1), 130-145. 
[20] Olsen, L. M., Vogt, C., \& Andereck, K. (2018). Sustaining the common good: tourism professional motives to volunteer for the tourism industry. Tourism Recreation Research, 43(1), 68-81.

[21] Omoto, A. M., \& Packard, C. D. (2016). The power of connections: Psychological sense of community as a predictor of volunteerism. The Journal of Social Psychology, 156(3), 272-290.

doi: 10.1080/00224545.2015.1105777

[22] Peterson, N. A., Speer, P. W., \& McMillan, D. W. (2008). Validation of a brief sense of community scale: Confirmation of the principal theory of sense of community. Journal of community psychology, 36(1), 6173.

[23] Petric, L., \& Pivcevic, S. (2016). Community based tourism development-insights from Split, Croatia. Paper presented at the Faculty of Tourism and Hospitality Management in Opatija. Biennial International Congress. Tourism \& Hospitality Industry.

[24] Pickett, A. C., Goldsmith, A., Damon, Z., \& Walker, M. (2016). The influence of sense of community on the perceived value of physical activity: a cross-context analysis. Leisure sciences, 38(3), 199-214.

[25] Rahi, S., \& Abd Ghani, M. (2016). Customer's perception of public relation in ecommerce and its impact on e-loyalty with brand image and switching cost. The Journal of Internet Banking and Commerce, 21(3).

[26] Rasoolimanesh, S. M., Jaafar, M., Ahmad, A. G., \& Barghi, R. (2017). Community participation in World Heritage Site conservation and tourism development. Tourism Management, 58, 142-153.

[27] Sanders, K., \& Canel, M. J. (2015). Mind the gap: Local government communication strategies and Spanish citizens' perceptions of their cities. Public Relations Review, 41(5), 777-784.

[28] Shaffee, N. S., Ahmad, E. M., Idris, S. I. Z. S., Ismail, R. F., \& Ghani, E. K. (2019). www.psychologyandeducation.net
Factors Influencing Accounting Students' Under-Performance: A Case Study in a Malaysian Public University. International Journal of Education and Practice, 7(1), 4153. doi: 10.18488/journal.61.2019.71.41.53

[29] Soylu, A. (2018). Digital Public Relations in SMEs. COMMUNICATION MEDIA \& PUBLIC RELATIONS, 35.

[30] Subramaniam, V., \& Anandasayanan, S. (2018). Capital Structure and Stock Prices: Empirical Evidence from Listed Beverage, Food and Tobacco Companies in Sri Lanka. International Journal of Social and Administrative Sciences, 3(2), 83-90. doi: 10.18488/journal.136.2018.32.83.90

[31] Suess, C., Baloglu, S., \& Busser, J. A. (2018). Perceived impacts of medical tourism development on community wellbeing. Tourism Management, 69, 232-245.

[32] Taiwo, S., Alagöz, M., \& Erdoğan, S. (2020). Inflation, Oil Revenue, and Monetary Policy Mix in an Oil-Dependent Economy: Empirical Insights from the Case of Nigeria. International Journal of Business, 7(2), 96109.

[33] Tang, Z. (2019). Economic Cycle and the Large-Scale Asset Allocation Strategy of Chinese National Social Security Fund. Asian Economic and Financial Review, 9(12), 1405-1418. doi: 10.18488/journal.aefr.2019.912.1405.1418

[34] Tarus, T. K., Tenai, J. K., \& Komen, J. (2020). Does Ownership Structure Affect Risk Management? Evidence from an Emerging Economy, Kenya. Journal of Accounting, Business and Finance Research, 8(1), 1-10. doi: https://doi.org/10.20448/2002.81.1.10

[35] Thomas, M., Fullerton, J., \& Saenz, L. M. (2018). Yield Spreads, The Exchange Rate, and Recession Predictability for Northern Mexico Border Economies. Asian Journal of Economic Modelling, 6(1), 56-64. doi: 10.18488/journal.8.2018.61.56.64 
[36] Tong, S., \& Baslom, M. M. M. (2019). Knowledge Management (KM) Practices in Education and Learning: Establishing a Knowledge Economy in Saudi Arabia. Humanities and Social Sciences Letters, 7(1), 1-9. doi: 10.18488/journal.73.2019.71.1.9

[37] Ul-Hameed, W., Mohammad, H., \& Shahar, H. (2018). Microfinance institute's nonfinancial services and women-empowerment: The role of vulnerability. Management Science Letters, 8(10), 1103-1116.

[38] Wright, D., \& Hinson, M. (2017). Tracking how social and other digital media are being used in public relations practice: A twelveyear study. Public Relations Journal, 11(1), 1-30.

[39] Wu, T.-c. (2018). Agriculture tourism and the transformation of rural countryside. Tourism Geographies, 20(2), 354-357.

[40] Xue, L., Kerstetter, D., \& Hunt, C. (2017). Tourism development and changing rural identity in China. Annals of Tourism Research, 66, 170-182.

[41] Yen, Y.-C., Chang, C.-H., Tien, J.-C., Shen, S.-C., \& Chang, H. H. (2019). Economic Implications Under Cross-Strait ExchangesTake Taiwanese College Students as an Example. International Journal of Asian Social Science, 9(1), 114-121. doi: 10.18488/journal.1.2019.91.114.121

[42] Yusufzada, S., Xia, Z., Poyan, S. M., Sediqi, M., Wahdat, M. N., Wafayar, Z., \& Sukhandan, M. N. (2020). Traffic Congestion in Kabul City and Suggestion for Sustainable Development. American Journal of Social Sciences and Humanities, 5(1), 194-206. doi: 10.20448/801.51.194.206

[43] Zahran, F. A. (2020). Internalization Perspective: Incorporating Intercultural Awareness in Language Teaching. International Journal of Social Sciences Perspectives, 6(2), 68-77. doi: https://doi.org/10.33094/7.2017.2020.62.68.7 7
[44] Zhang, S. (2019). Public participation in the Geoweb era: Defining a typology for geoparticipation in local governments. Cities, 85, 38-50.

[45] Zhu, H., Liu, J., Wei, Z., Li, W., \& Wang, L. (2017). Residents' attitudes towards sustainable tourism development in a historical-cultural village: Influence of perceived impacts, sense of place and tourism development potential. Sustainability, 9(1), 61. 